\title{
Gravity and Geodetic Studies in India: Historical Observations and Advances During the Past Decade
}

\author{
N SRINIVAS and V M TIWARI* \\ CSIR-National Geophysical Research Institute, Hyderabad 500 007, India
}

(Received on 14 June 2018; Accepted on 16 October 2018)

\begin{abstract}
Gravimetry and Geodesy deal with the mass distribution and transport in the dynamic Earth system and determination of Earth's shape and size. Since the 18th century, Indian scientists have been extensively contributing to the progress of Gravity and Geodetic studies. This article discusses the historical geodetic developments and summarizes the efforts that involve measurements and modelling of gravity and geodetic data in India over the past decade, using conventional land surveys to satellite observations. Historical obsevations, such as the Great Trigonometrical Survey during 1790-1850 for defining geodetic reference frame and gravity and geodetic observations in the Himalayan region (1830-1843) for hypothesising the concept of Isostasy, are phenomenal contributions made from studies in India. Recent studies are largely focused on understanding of subsurface mass distributions and mass variability due to different geophysical phenomenon, refining of geodectic datum, continental deformation and resource exploration.
\end{abstract}

Keywords: India; Gravity; Geodesy; Geoid; Datum

\section{Introduction}

The gravity and geodetic research worldwide has evolved as a scientific interface to facilitate the integration of satellite-based observations with the terrestrial measurements thereby making all earth observations interoperable.Both gravimetric and geodetic (using land, marine, borehole, airborne and satellite-based) studies have made tremendous progress during the past few decade and provided valuable insights with regard to the behaviour of spatio-temporal dynamics of the Earth (Tiwari, 2010). There has been an increased focus on precisely defining the local and regional geoid models worldwide due to their significance in the areas of applied geophysics and geodetic studies. Apart from the use of geoid in the engineering applications of surveying (geodesy), the detailed knowledge of geoid undulations at different wavelengths areused to infer the subsurface mass distributionsin the Earth ( $\mathrm{Li}$ and Götze, 2001).

There are numerous studies on the interpretation of geoid in terms of mass anomalies at depth, tectonic forces, isostatic state of the oceanic lithosphere, Earth's rotation, total water storage and ocean circulation (e.g., Bowin, 2000). The gravitational potential decreases with distance from the surface of the Earth at a slower rate than the gravity, the geoidal variations tend to reflect deeper mass anomalies compared to the gravity anomalies (Hackney, 2004). The geoid anomalies thus provide information in terms of the subsurface mass distribution and dynamics of the Earth (Bowin, 2000; Vanicek and Christou, 1993; Featherstone, 1997).

The Indian geoscientific community, particularly during the post-independence era, has made significant scientific progress and achievements in tandem with the developments that took place worldwide in gravity and geodetic studies. These studies have led to several improvements in the Indian geodetic datum that was established in $19^{\text {th }}$ century by the Survey of India (SOI), preparation of gravity anomaly maps using dense terrestrial gravity measurementsand the integration of satellite-based gravity data with groundbased observations for various applications by different organizations. This paper is intended to provide a brief

*Author for Correspondence: E-mail: virendra.m.tiwari@gmail.com 
overview of the historical development of the gravity and geodetic measurements in India with special emphasis on the recent studies/research work carried out by the Indian researchers in the allied areas of gravity and geodesy for various applications.

\section{Brief History of Gravity Surveys in India}

Gravity surveys in India were initiated in 1865 by J.P. Basevi and W.J. Heaviside, British Captains, using two brass pendulums provided on loan to Government of India by Royal Society of England for establishing about 30 gravity stations from Kanyakumari to Ladakh during 1865 to 1873 (Walker et al., 1901). Subsequently, Sterneck's half-second pendulums (1902 to 1925) and Cambridge pendulums (1926 to 1939) were used to establish 564 pendulum stations by the SoI in the different parts of the country. The pendulum measurements were suspended on account of the World War II from 1939 to 1947. The First gravimeter used in India was Frost gravimeter in 1947. Afterward, different organizations have procured gravimeters for the geophysical exploration, educational and training purposes. The systematic surveys were started during 1950s by the dedicated geodesists and geophysicists and continued over the years to map the subcontinent of India covering the northern mountains, the peninsular plateau, IndoGangetic plains, dense forests, deserts and coastal regions. Data of about 3000 gravity stations including 564 pendulum stations recorded during 1902-1955, have been published by Gulatee (1956).

Precise determination of the height of the Mount Everest is one of the most celebrated achievements in the history of Indian gravity and geodesy. The National refence gravity station, tied with Potsdam gravity basewas established at SOI, Dehradun and a North-South calibration line was set up (Manghnani and Woollard, 1963). Hari Narain et al. (1964) examined the status of gravity work in the country and found that a considerable amount of available gravity data were mostly referred to the old pendulum stations of SOI, which had irreconcilable discrepancies. Further, the entire gravity data in the country was brought on to a common datum tied appropriately to the World Gravity Net andused for the geodetic and crustral studies in India. NGRI initiated a National Gravity Programme of preparation of regional gravity studies of India in 1964 which led to the publication of a series of gravity maps of India in 1975.

Gravity base network was established and the gravity values were published in different parts viz Part-I:-150 gravity bases in South India (Qureshy and Brahmam, 1969); Part-II:- 93 gravity bases in Northern and Western India (Qureshy and Warsi, 1972); Part-III:- 50 gravity bases in North India (Qureshy and Warsi, 1973);Part-IV:- 125 gravity bases in North Eastern India (Qureshy et al., 1973) and Part-V:- 16 gravity bases in Central India (Subba Rao et al., 1982).During these investigations, several of the SOI stations were reoccupied for standardization anda few new first order and secondary gravity bases were also established by various organisations(Murthy et al. 1976; Verma et al. 1979; Singh et al., 1986 and Radhakrishna et al., 1998). Regional gravity surveys carried out by GSI over the Deccan traps during 1964-1970 delineated two major lineaments, one along the west coast and other along the 21 st parallel degree north of the Earth's equatorial plane (Kailasam et al ., 1972). A detailed gravity survey covering 1900 gravity measurements in the Singhbhum region was carried out, which revealed Bouguer anomalies ranging from $+10 \mathrm{mGal}$ in the eastern part to about $-60 \mathrm{mGal}$ over the Singhbum granite batholith (Verma et al., 1984). Further, a large numberof gravity measurements are carried out under the National Gravity Programme by SOI. GSI launched National Geophysical Mapping (NGPM) programme during the 2002-2003 with an objective to generate gravity and magnetic responses in potential areas of mineral exploration.

\section{Gravity Map Series of India}

In the year 1975, the voluminous gravity data at National Geophysical Research Institute (NGRI), Survey of India (SOI), Oil and Natural Gas Commission (ONGC) and the Hawaii Institute of Geophysics (HIG) were compiled and the first ever Gravity Map series of India (1975), with 10 m Gal contour interval was published on 1:5 million scale. These maps were based on 30000 gravity stations located along the major roads at intervals of $6-8 \mathrm{~km}$, where benchmarks or spot heights were readily available.In case of geodetic data gaps, two altimeters were simultaneously operated to obtain elevations of the gravity stations. Taking into account all the factors 
that contribute to errors in the Bouguer anomaly values, the anomalies could be accurate within $\pm 1.5 \mathrm{mGal}$. In case of the Himalayan region, however, such accuracy could not be obtained for stations for which the elevations were acquired using altimeters. This set of maps - Bouguer Gravity, Free-Air and Isostatic anomaly maps, led to formulate new exploration activities in India besides someimportant basic research such as refining the ideas of isostasy. The relationship between gravity anomalies and elevation was empirically derived and used to predict the thickness of the crust. These maps are further upgraded as Gravity Map of India (2006; Fig. 1(A)), a collaborative effort of several organisations; NGRI, Geological Survey of India (GSI), Oil and Natural Gas Commission (ONGC), Oil India Limited (OIL) and Survey of India (SOI). Data from 51,356 gravity stations at 3 arc interval are included with the implementation of detailed terrain corrections to the gravity stations, new theoretical gravity formula based on the Geodetic Reference System 1980 (GRS80) and the International Gravity Standardisation Net 1971 (IGSN71) datum. These revised maps are prodigious assset to the geosceince researchers and explorers. A brief description of the gravity anomaly map in relation to the geological features is given below.

\section{Bouguer Gravity Anomaly Map}

A mjor feature of this map is the predominance of negative Bouguer anomalies over the subcontinent reaching to value of $-380 \mathrm{mGal}$ over the Himalaya. A few pockets of positive Bouguer anomalies are observedon the west coast and reaching to a maximum value of $+60 \mathrm{mGal}$ near Bombay. The anomalies exhibit alignments/trends parallel to the major structural trends of the subcontinent such as the NNW-SSE Dharwarian trend of South India, NE-SW Eastern Ghat trend parallel to the east coast of South India, NE-SW Aravalli trend of North-Western India, ENE-WSW Satpura trend of Central India and the Himalayan trend. Besides these regional trends, there are several gravity 'highs' and 'lows' reflecting local geological features. The sediments of the Vindhyan and Gondwana basins, sedimentary tracts of the east coast, intrusive granites of Peninsular India are all characterised by gravity 'lows.' Gravity 'highs' are observed over the Eastern Ghats, south-western Cuddapah basin, the Satpura and Aravalli ranges. In contrast, there are also areas where the Bouguer anomalies do not readily correlate with surface geology. Prominent among themare the 'lows' over the Deccan Traps of Western India, eastern Cuddapah basin, Peninsular gneisses of south India and Bastar region. The area west of Aravalli, which is mostly covered by alluvium, is a zone of mixed highs and lows. Synclinal structures filled with sedimentary or metasedimentary formations, volcanics, basic and ultrabasic intrusions, granitic intrusions of batholithic, differentiation of granites are inferred as gravity high in the Singhbhum group, Dhanjori and Simlipal basins in East India. The gravity high revealed in the North Eastern India, Shillong Plateauindicates the presence of relatively higher density underlying rocks. Strong negative anomalies as in Assam Valley, eastern Himalaya and Arakan-Yoma indicate areas characterized by mass deficiency due to a thickening of sediments and root formation or both. Gravity anomalies over India are used to construct crustal and lithospehric density models (e.g. Tiwari et al., 2013).

\section{Brief History of Geodetic Studies in India}

\section{Indian Horizontal Datum}

The Indian Horizontal Datum adopted the Everest ellipsoid as the local geodetic datum in 1830. It is nongeocentric and the oldest among all the principal ellipsoids. The source of Everest ellipsoid set at Kalianpur with the initial point position of $24^{0} 07^{\prime}$ $11.26^{\prime \prime} \mathrm{N}$ and $77^{0} 39^{\prime} 17.57^{\prime \prime} \mathrm{E}$. The center of the Everest ellipsoid does not coincide with the center of the Earth however, it is locally the best fitting ellipsoid to the Indian subcontinent. SOI generated topographical maps on 1:50,000 and 1:25,000 with reference to Everest ellipsoid for expressing geographical coordinates of places in India more than 150 years back. SOI has revised the ellipsoids from time to time (i.e., International (Hayford), GRS80 and WGS84) leading to the revision of the parameters assumed for the ellipsoid. Advancement satellite geodesy in satellite tracking technology has provided geodesists with new measurements such as VLBI, SLR, DORIS and GNSS to define the best Earthfitting ellipsoid and for relating existing coordinate systems to the Earth's center of mass. Accurate World Geodetic System (WGS84) ellipsoid was established using new gravity data, astro-geodetic measurements, satellite configuration and earth-fixed 
models (ECEF). WGS84 datum is a geocentric geodetic datum and globally consistent within +1 meter, which does not change from place to place or from country to country.

\section{Indian Vertical Datum}

Vertical datum, which nearly coincides with mean sea level, provides the height information. In other words, the geoid is a visual representation of zero elevation which is considered to be reference height. This datum is derived based on tidal observations, astronomical, GNSS-levelling and gravimetric measurements. MSL is described as a tidal datum that is the arithmetic mean of hourly water elevations observed over a specific 19-year cycle (Aung et al., 2009). SOI has been using the astrogeodetic geoid for the Indian vertical datum observations with respect to Everest ellipsoid since 1840 and using the first-order levelling Bench Marks (BM) measured in the early nineteen century (Fig. 1(B)). Fore and back levelling and invar staves instruments were used for measurements. The first vertical datum for India was establieshed based onadjustment of leveling network, which had included data collected from 1858 to 1909 and referenced to MSL values of nine tide gauge stations and limited number of surface gravity observations.

\section{Significant Contributions in Gravity and Geodetic Research During the Past Decade in India}

\section{Salient Outcome of the Geodetic Research}

Everest datum, which was developed using a small volume of data, is not suitable for high precision geodetic and allied activities of the modern age. Utilizing open source global products for positioning, the datum transformation from Everest coordinate system to geocentric coordinate system (ITRF) was initiated in the $21^{\text {st }}$ century (Singh, 2010). SOI has set up a Ground Control Point (GCP) Library, as a part of which 292 primary control points were established at a spacing of $250-300 \mathrm{~km}$ in the first phase. In the second phase,the network was strengthened with 2200 GCP Library pillars with an interval of about 30-40 $\mathrm{km}$ and in the third phase, further 65,000 GCP of 6-7 $\mathrm{km}$ spacing were added to provide necessary horizontal reference points. SOI completed the high precision levelling network with an adjustment of $45,775 \mathrm{~km}$ along the national and state highways, as a part of redefining Indian vertical datum project (Fig. $1(\mathrm{C}))$.
Nagarajan and Singh (2010) demonstrated the utilisation of GPS to provide planimetric coordinates of GCP's with $1 \mathrm{~m}$ control interval for initiating a comprehensive development plan for the Bangalore metropolitan area. GPS vertical datum has turned out to be a progressive tool in establishing a vertical network for engineering applications, though it has certain limitations. In the recent years, most of GTS benchmarks got destroyed due to urbanisation and industrial development. There are global gravity models that allow determining geoidal undulations; however, the global models are constrained by spatial resolutions. Determination of geoid undulations over southern Indian region is of specific importance because the largest geoid depression in the world is centered in the Indian Ocean encompassing South India (Marsh, 1979) and therefore a large spatial gradient of geoid undulation is observed in this region. Geoid height decreasing towards south reaching up to the minimum value of $-106 \mathrm{~m}$, located in the Indian Ocean, is generally known as Indian Ocean Geoidal Low (IOGL). The cause of this anomaly is attributed to the depression in the Core-Mantle boundary, relict of earlier subduction and so on. The wavelet analysis of the corresponding gravity low in the IOGL provides depth at $\sim 1260$ and $\sim 693 \mathrm{~km}$ reported by Tiwari and Goyal (2010). Modeling of the large wavelength regional gravity anomaly corresponding to the IOGL provides a three-layer model at depths of 1300, 700 and $340 \mathrm{~km}$ (Mishra and Ravikumar, 2012) related to the spectral depths obtained from the geoid and regional gravity data with negative density contrasts. The relatively short wavelength sources of the spectrum of the geoid data at depths of 162 and $85 \mathrm{~km}$ suggest sources along the lithosphere-asthenosphere boundary $(\mathrm{LAB})$ under the Indian continent and surrounding oceans, respectively. All the studies of this long wavelength geoidal low suggest a deep causative source, a density heterogeneities in the mantle. Upper to middle mantle low-density anomalies are mainly responsible for the formation of IOGL and are clearly explained by the presence of low-density anomalies in the $\sim 300-900 \mathrm{~km}$ depth beneath the IOGL (Ghosh et al., 2017). Some of the recent studies attempted to compute an accurate geoid model without terrestrial gravity observations. Goyal et al. (2018) have shown that the EGM2008 model is the best GGM available for India with an accuracy of $28 \mathrm{~cm}$, without model fitting. Similarly, GOCE GGM has demonstrated 

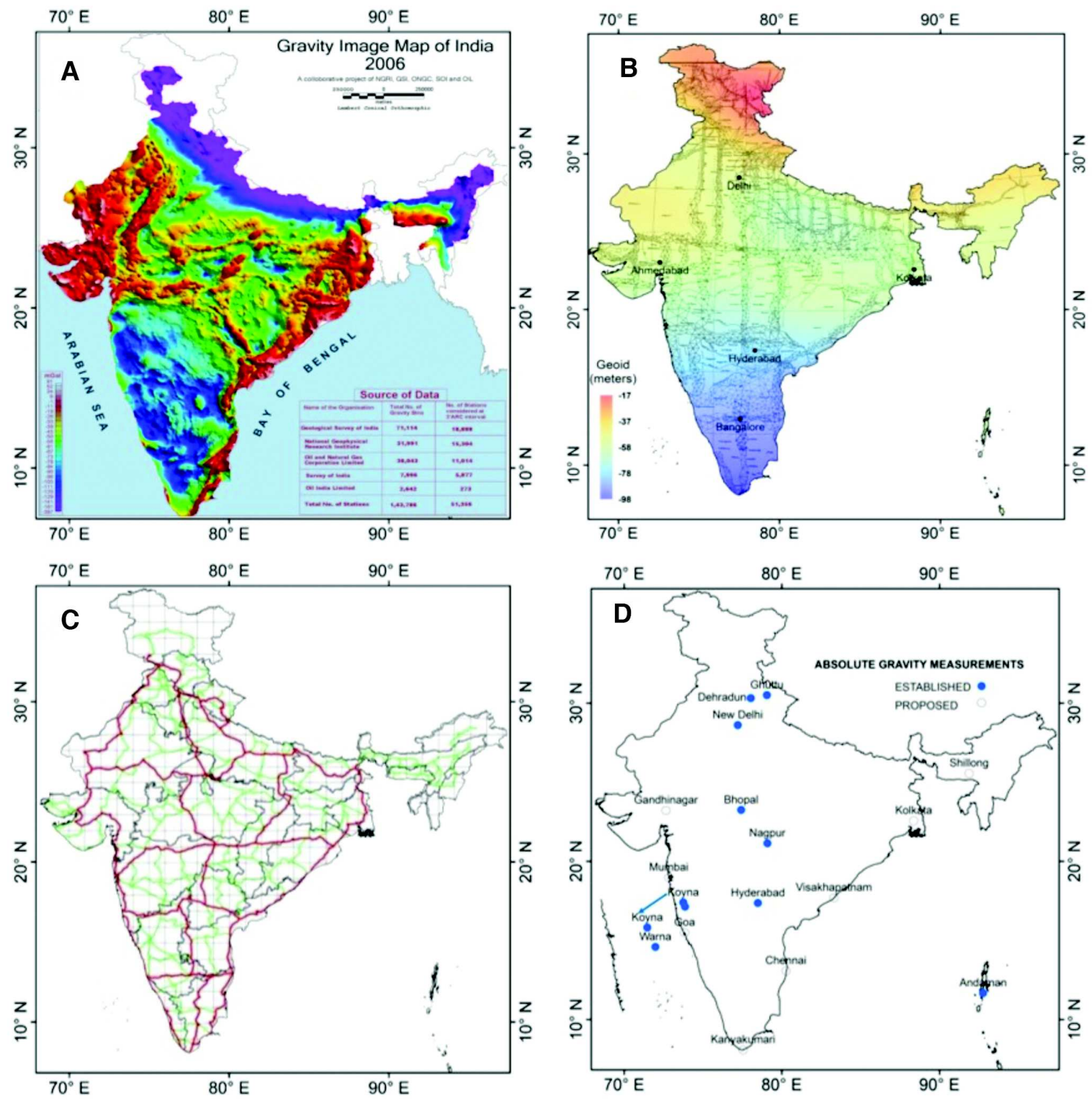

Fig. 1: (A) Bouguer gravity anomaly map of India :Gravity Map Series of India-2006; (B) Spatial distribution of GTS benchmarks in India (1905) (source: Wikipedia); (C) Status of high precision levelling (after Singh and Srivastava (2018)) and (D) Locations of established/proposed precise gravity reference stations in India using the absolute gravimeter

significantly better results with an accuracy of $19 \mathrm{~cm}$ for India after modelling with seven parameterisations. SOI developed the first version of Indian Geoid model called INDGEOID ver 1.0 in $250^{\text {th }}$ year celebrations of Surveying and Mapping activities in India in 2017.

\section{Local Geoid Determination}

Orthometric height is the height of the surface above or below the geoid. Precise information of geoid undulation is vital for understanding the subsurface mass distribution of the Earth. The geoid surface is not an actual physical figure of the Earth, thus it cannot be directly measured. The current point-based geodetic height determined using GPS-levelling is not sufficient to generate the accurate geoid surfacefor any application. The determination of orthometric heights over a local area is obtained through the GPSlevelling observations or calculated from terrestrial 
gravity values. Few attempts were made for computation of gravimetric geoid and the results were compared with GPS-levelling measurements over the Indian subcontinent (Singh et al., 2007; Carrion et al., 2009; Srinivas et al., 2012; Singh and Srivastava, 2018). Ghosh and Mishra (2016) determined the geoid undulation for Dehradun using the astro-geodetic method in conjunction with GNSS observations. The accuracy of the computed geoid has been found to be better than global geoid models. Mishra and Ghosh (2017) computed accurate geometrical geoid model in Dehradun with the help of sufficiently dense and homogeneous control stations. The advantage of the geometrical approach of geoid modelling is its being non-dependence on gravity field or deflection of vertical. Utilization of existing gravimetric data may provide the precise geoid surface with the help of different geoid computational methods such as Remove Compute Restore (RCR) method, StokesHelmert method, Least squares modification of Stokes formula etc. SOI derived the optimised solutions of the local gravimetric geoid with Free Air gravity anomaly data for some region of the Indian subcontinent by implementing the RCR method. GPSLevelling Points: 84 (Bangalore city: Singh et al., 2006), 50 (Delhi region: Singh et al., 2007) and 72 (Central India: Singh, 2007) were selected for performing a realistic assessment of geoid model and subsequently optimised the integral parameters of Stokes Formula. The RCR procedure has been applied to combine the GGM, high-frequency height data from a DEM and local terrestrial gravity anomaly data. The hybrid geoid model has shown a considerable improvement over gravimetric geoid, and standard deviation of post-fitting residuals is improved to approximately $5 \mathrm{~cm}$ precision after the Least Square Collocation (LSC) technique.

Carrion et al. (2009) computed the geoid undulations over a part of southern Indian region with terrestrial gravity data using the RCR technique to calculate Stokes coefficients and compared with EGM2008 global geoid model with a difference of fewer than two meters. Similarly, Prajapati and Singh (2010) determined the residual geoid for some of the Indian plateaus (i.e., Saurashtra, Malwa, Satpura, Ajanta) by removing the effects of geopotential model, Free-air gravity anomalies and height data by applying the LSC technique. The geoidal undulations suggest that the primary source of geoidal high lies within the crust-upper mantle. Another attempt is made to compute and validate the geoid undulations (Fig. 2) concurrently using terrestrial gravity data and GPSlevelling observations and to compare them with geoid undulations obtained from global geopotential models over the southern part of India (Srinivas et al., 2012). An agreement between GPS-levelling data and global geopotential model was found on a regional scale. However, geoid from GPS-levelling over a small region is considerably adequate to the gravimetric geoid and suitable for the local applications.

Geoid undulations are also derived from LiDAR survey and GTS benchmarks over the Kosi and Mahanadi basins and compared with the GOCE derived geoid heights. A bias of $1.5 \mathrm{~m}$ with reference to the ground geoid is reported by Satishkumar et al. (2014). The hybrid geoid is a combination of the Geometric geoid and Gravimetric geoid. Tripathi and Tripathi, (2015), utilised the terrestrial gravity, elevation and positioned data of 190 GPS-Levelling data spread across Chhattisgarh region to calculate the hybrid geoid with an accuracy of $60 \mathrm{~cm}$. Mishra and Ghosh (2016) also adopted the RCR method to determine gravimetric geoid for two different types of topographical regions (i.e., Hyderabad and Dehradun) and achieved $\sim 20 \mathrm{~cm}$ accuracy in the highly elevated Himalayan region and $\sim 10 \mathrm{~cm}$ in the gentle elevated Hyderabad region.Singh and Srivastava (2018) explained the development of Gravimetric geoid model for Western India using the RCR method and implemented the spherical Fast Fourier Transformation (FFT) with optimised Stokes's kernel to achieve an accuracy of $14 \mathrm{~cm}$ for gravimetric geoid and $7 \mathrm{~cm}$ for hybrid geoid model with the help of GNSS observations on first order benchmarks at 39 locations. SOI initiated a program "Redefinition of Indian Vertical Datum" by optimal utilisation of existing gravity GNSS and levelling data to develop a hybrid geoid model, to achieve an accuracy of better than $10 \mathrm{~cm}$.

\section{High Precision Gravity Measurements}

The absolute gravity (AG) observations across India and at Maitri, Antarctica were first carried out by NGRI, to establish reference gravity stations with aprecision of $1 \mu \mathrm{Gal}$ using Micro-g LaCoste FG5 absolute gravimeter. A reference gravity base station was established with an accuracy of about 2-3 $\mu \mathrm{Gal}$ with the help of Absolute Gravimeter (FG5 \#219) at 




Fig. 2: Residual geoid and gravimetric geoid of a part of south India (after Srinivas et al., 2012)

the NGRI Gravity Observatory, Hyderabad (Tiwari et al., 2006b). New precise reference gravity base stations were established in different parts of India (New Delhi, Dehradun, Ghuttu, Bhopal, Nagpur, Koyna, Warna, Port Blair and Maitri, Antarctica (Tiwari et al., 2006b)). The AG observations comprised of regular repeat measurements over a network of existing and proposed absolute gravity sites (Fig. 1(D)) throughout India to provide information about the mass redistribution, vertical deformation and metrological applications (Tiwari et al., 2014a).

The Superconducting Gravimeters (SG) are in operation at two locations in India, Ghuttu by WIHG, Dehradun (Arora et al., 2008) and Badargadh by ISR, Ahmadabad. The SGs continue to provide a high precision record of the time variation of gravity with an accuracy of nGal. SG observations at both the above locations are located by other geophysical observations with the primary objective of earthquake precursory studies. Chauhan et al. (2016) observed the annual variations in SG gravity data at the rate of $112 \mathrm{nms}^{-2} /$ year with a variation of $16 \mathrm{~m}$ in water table level and vertical displacement of $2.2 \mathrm{~mm} /$ year. Repeat AG observations are being madeat the site of $\mathrm{SG}$ located in the Himalayan region for drift corrections and calibration of SG. Gravity variations using gPhone gravimeter are being continuously recorded at Warna, Maharashtra, a seismically active region of peninsular India for investigation of potential gravity changes related to seismic activities. Prasad et al. (2017) successfully demonstrated the temporal gravity changes recorded by using gPhone and GRACE satellite and interpret the observed changes in conjunction with seismological, geodetic (cGPS) observations and groundwater level measurements.

\section{Satellite Gravimetry}

Most of the Indian researchers engaged in the observation and modelling of the earth's gravity field are focusing on deciphering tectonic and geodynamic processes that have shaped the present day lithospheric structure. The studies are carried out over the diverse tectonic and geological setting of the Indian subcontinent through a large number of gravity data in peninsular India. Since ground and marine gravity measurements cannot adequately cover the Indian subcontinent and adjoining ocean, satellite measurements are often oused. High-resolution Gravity field determination from space can be obtained from various measurement methods, namely Satellite radar altimetry (Geosat, European Remote Sensing (ERS-1), CryoSat-2, Jason-1, Saral-Altika), Satellite-Satellite tracking (CHAMP and GRACE), Satellite Gravity Gradiometry (GOCE). Since summarising the results from all the studies goes beyond the scope of this review article, results from selected studies of satellite gravimetry are briefly mentioned.

\section{Applications of Satellite-derived Gravity for Crustal Studies}

Applications of satellite gravimetry in India are reported in several studies related to exploration of natural resources, lithospheric structure, hydrological changes and geodynamics studies. Bhattacharyya et al. (2009) generated a composite high-resolution freeair gravity anomaly map for the Arabian Sea from Seasat, Geosat GM, ERS-1/2 and Topex/Poseidon altimeters data. Satellite altimetry derived gravity combined with terestrial gravity data provide enhanced imaging of geological features of Indian penesula and adjoining ocean basins (Majumdar et al., 2001; Mishra et al., 2004 and 2012; Mishra and Tiwari, 2008; Mishra and Rajasekhar, 2005; Tiwari et al., 2007 and 2013; Tiwari and Mishra, 2008; Chatterjee et al., 2007; Mishra and Ravikumar, 2012; Ravikumar et al., 2013a; Ravikumar et al., 2013b; Kumar et al., 2013; Kumar et al., 2014; Rajesh and Majumdar, 2014; Singh et al., 2015), Bay of Bengal (Radhakrishna et al., 2000; Rajesh and Majumdar, 2003; Radhakrishna et al., 2010; Nandi and Rao. 2015; Kar et al., 2015; Rao et al., 2015; Rao et al., 2016; Dubey et al., 2017), continental margins of India (Chand et al. 2001; 
Subrahmanyam and Chand, 2006; Mishra, 2011; Sreejith et al., 2013; Murray, Laxmi, ChagosLaccadive, $85^{\circ} \mathrm{E}$ and $90^{\circ} \mathrm{E}$ ridges (Tiwari et al., 2003; Bansal et al., 2005; Subrahmanyam et al., 2008; Rao and Radhakrishna., 2014; Rajesh et al., 2015; Nair et al., 2015; Majumdar and Chander, 2016), Western Continental Margin of India (RadhaKrishna et al., 2002; Arora et al., 2006; Mukhopadhyay et al., 2008; Rao et al., 2010; Arora et al., 2012; Majumdar and Bhattacharyya, 2014; Rao et al., 2018), Eastern Continental Margin of India (Singh and Diljith, 2009; Bhanja Bastia et al., 2010; Radhakrishna et al., 2012; Desa et al., 2018), Andaman arc (Grevemeyer and Tiwari, 2006; Radhakrishna et al., 2008); Himalayan region (Rajesh and Mishra, 2003; Tiwari et al., 2006a,2009a, 2010 and 2014b) Antarctica (Majumdar et al., 2018). A 3D lithospheric density model of the Andaman-Sumatra subduction zone is constructed from joint modelling of satellite-derived gravity and geoid data (Yadav and Tiwari, 2018). The geophysical mapping of Singhbhum-Orissa Craton and Jharia Coalfield are carried outusing the GOCE, EGM2008 and EIGEN6-C2 and compared with the in-situ gravity (Pal and Majumdar, 2015; Vaish and Pal, 2015; Pal et al., 2016).

A revised gravity anomaly map of the $85^{\circ} \mathrm{E}$ Ridge (Pal et al., 2016) and Bay of Bengal (Narayan et al., 2017) was generated utilizing the EIGEN6C4 global gravity model. Singh et al. (2015) analysed satellite gravity and geoid anomaly and topography data to determine the 3D lithospheric density structure of the Singhbhum Protocontinent. Kalra et al. (2014) interpreted the occurrence of sub-basalt sediments at the margin using the satellite gravity and encapsulated to provide a basis for assessing deepwater petroleum prospect of the entire western margin offshore. Rao and Radhakrishna (2016) carried out evolutiontests based on the statistical estimates, spectral analysis and image enhancement filters have been performed to assess the spatial resolution and quality of Earth Gravitational models (EGM2008, GOCE, DTU13 and SSV23.1) and crustal magnetic field model (EMAG2) over the Indian shield and its surrounding offshore regions.

\section{Hydrogeodesy}

Hydrogeodesy is referred to the application of geodetic techniques to the study and monitoring of the terrestrial waters. Dedicated gravity mission senses the spatiotemporal variations of the gravity field caused mainly by the hydrological mass changes in the Indian region and glaciological mass changes over the Himalayan region. Tiwari et al. (2009b) estimated a massive loss of groundwater in Northern Indian region at a rate of $54 \pm 9 \mathrm{Km}^{3} / \mathrm{yr}$ from 2002 to 2008 utilizing the GRACE data with a combination of hydrological (Fig. 3). The hydrological signal derived from GRACE was also validated with in-situ measurements in India and demostrated the application in the monitoring of water storage (Tiwari et al., 2011 and 2014a; Bhanja et al., 2016, 2017a; Asoka et al., 2017). The GRACE dataset reveals a declining trend of groundwater in different parts of the Indian subcontinent (Tiwari et al., 2009b; Khan et al., 2013; Dasgupta et al., 2014; Banerjee and Kumar 2014; Chinnasamy et al., 2015; Verma et al., 2016; Gautam et al., 2017a; Banerjee and Kumar 2016; Singh et al., 2017; Mukherjee and Ramachandran, 2018). Lowering of groundwater storage are caused due to anthropogenic groundwater withdrawals to sustain rice and wheat cultivation in the Ganga basin (Panda and Wahr, 2016; Barik et al., 2017). The GWS depletions that constitute about $90 \%$ of the observed TWS loss are influenced by a marked rise in temperatures since 2008. Bhanja et al. (2017b) noted that the paradigm shift in Indian groundwater withdrawal and management policies for sustainable water utilization appear to have resulted in replenishing the aquifers in western and southern parts of India. GRACE data are also used for detecting significant extreme events, such as flash floods of Mumbai 2005 and Bihar 2008 (Dutt Vishwakarma et al., 2013); drought 2015 (Mishra et al., 2016; Sinha et al., 2017), heat waves (Panda et al., 2017). Soni and Syed (2015) estimated the influence of ENSO on ground water storage in major river basins of India.

\section{Hydrological Loading}

Indian subcontinent receives a considerable amount of mass in the form of rainfall during south-west (summer) monsoon season and partly during northeast (winter) monsoon period. The mass influence causes the hydrological loading on the crust surface depending on the geological provinces and its intensity. GPS and GRACE data sets can sense this hydrological loading behaviour that may lead to crustal deformation and tectonic movement. Tiwari et al. (2014a) analysed the influence of hydrologic loading on vertical 

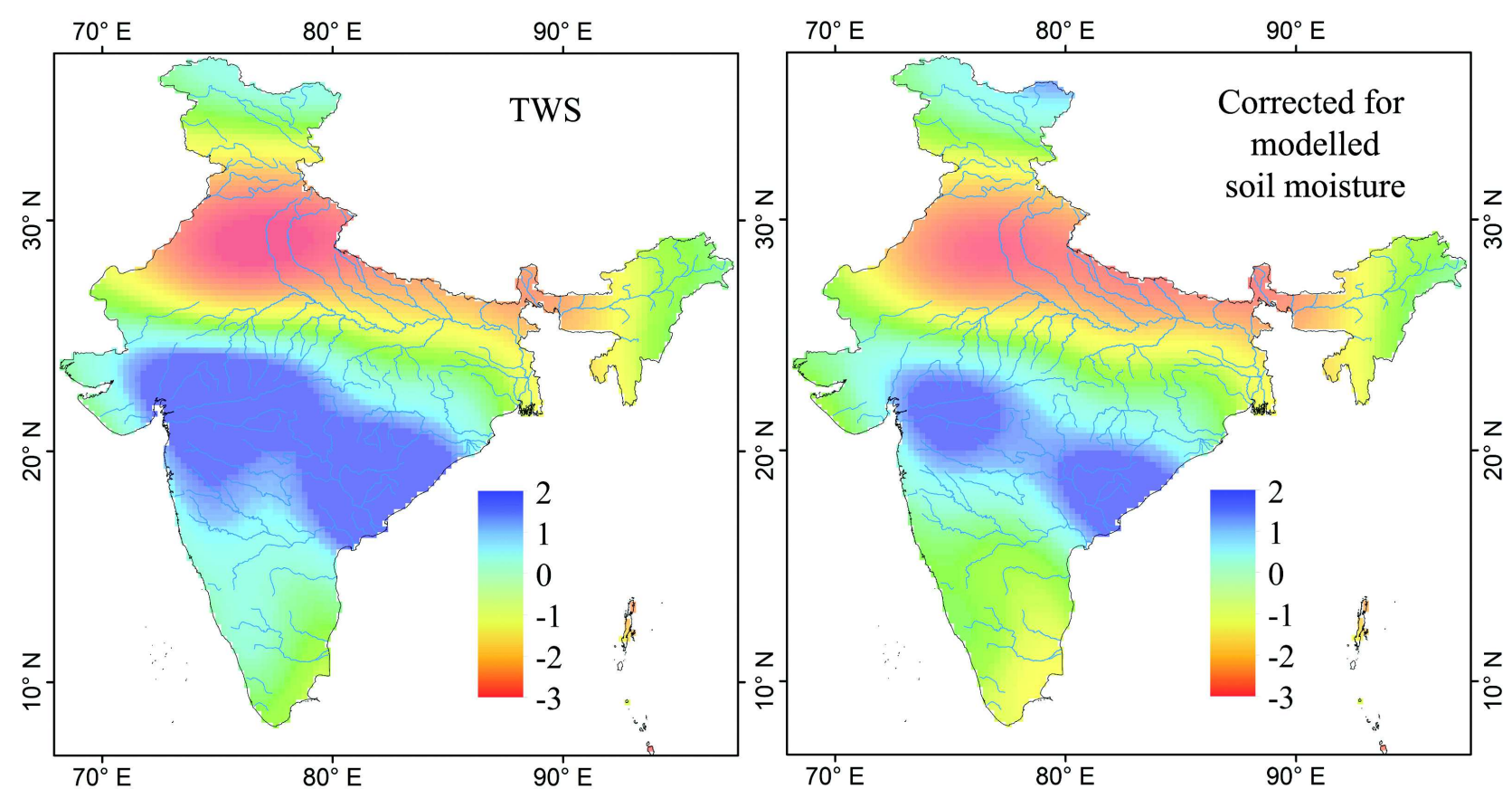

Fig. 3: Rate of change of Total Water Storage (TWS) in the Indian subcontinent (after Tiwari et al., 2009b)

deformation over South India (1-2 cm) and compared with data derived from GRACE (Fig. 4). Khandelwal et al. (2014) correlated the GPS data with the water load storage in the Ganga plains, with the minimum in displacement coinciding with the maximum storage of water in Ganga plains immediately after the monsoon and vice versa. Such variations also appear to cause the annual variation in the low-magnitude earthquake frequency in the Himalayan region, being relatively more in the winter period. The anthropogenic groundwater unloading in the Indo-Gangetic plains influenced $2015 \mathrm{Mw} 7.8$ Gorkha, Nepal earthquake that occurred on the MHT beneath the Himalayan arc (Kundu et al., 2015). Seasonal variations in the Himalayan region are the most prominent in the vertical and north components of GPS time-series. Gahalaut et al. (2017) explained the combined effect of the local reservoir water load and the regional hydrological and atmospheric loading of Tehri reservoir in the Garhwal region of NW Himalaya from the GPS and Interferometric Synthetic Aperture Radar (InSAR) analysis. Kundu et al. (2017) demonstrated thatthe evaporation induced unloading in the Himalayan foothills and adjacent Indo-Gangetic plains during the post-monsoon period adds a significant component of horizontal compression to the interseismic contraction at the MHT, which is the primary driving mechanism for the seasonal modulation. The influence of seasonal loads is maximum in the vertical component which decreases in the north and then in the east component in the Garhwal-Kumaun Himalaya (Gautam et al., 2017b). Prasad et al. (2017) estimated the hydrological loads of Koyna warna region (KWR) from GPS and GRACE of regional water storage and reservoirs storage, which can lead to the perturbation of stress condition as well as pore pressure condition at the depth.

\section{Airborne Gravity Gradiometry}

Airborne gravity gradiometry (AGG) can provide a gravity map efficiently over a large, highly inaccessible undulating region in a short period with an accuracy of 5-10 Eötvos over a wavelength of 400 meters. AGG data can be used for the mapping of subsurface structure with a good spatial resultion. Successfully, the first Airborne Gravity Gradiometer (AGG) survey in India has been carried out through Fugro Falcon Airborne System over the rugged terrain of the Western Ghats in the KWR of Maharashtra to infer subsurface structure as a prelude to the first deep scientific drilling in the region. Joint inversion of AGG 



Fig. 4: Comparison of daily and seasonal variations of vertical velocity from GPS \& vertical elastic deformation using GRACE data in major cities in Hyderabad and Bengaluru (after Tiwari et al., 2014a)

datasets allowed to propose 3D structural setting beneath KWR and across the Western Ghats. In this Survey, AGGM data covering 5,012 line km were recorded along N-S flight paths at an average $120-\mathrm{m}$ drape surface, cutting across the Koyna seismic zone. The subsurface model provides thickness of the Deccan basalts varying from 400 to 1,700 meters in the KWR (Gupta et al., 2015). Deccan basalts are thicker on the eastern side of the topographic escarpment compared to the western side (Gupta et al., 2017).

\section{Studies for Exploration of Natural Resources}

Several central and state government organizations, such as GSI, ONGC, OIL and other exploration companies have extensively acquired gravity data in different basins for regional prospecting. Some of the target areas are basins located in northwest India, Godavari basin, Rewa basin and frontier basins of northeast India. There have also been efforts to map the mineral resources (Mishra, 2011), exploration of hydrocarbons (Singh et al., 2012) and sub-basalt 
sediments (Goyal and Tiwari, 2014). Gravity measurements are made for mineral exploration in different parts of the country by GSI and exploration companies. Several studies at specific localities are taken up for mineral prospecting purposes (http:// www.portal.gsi.gov.in). One of the new initiatives was gravity survey for manganese exploration in the Nagpur and Bhandara districts of Maharashtra. Gravity survey carried out in Meghalaya revealed gravity high in the southern part over tertiary rocks corresponding to the high-density intrusive metavolcanics and also due to Khasi Greenstones including epidiorite. Gravity observations recorded for structural mapping and location of mineralized zones in the parts of Singhbhum brought out the disposition of the Copper belt.

\section{Tectonic Geodesy}

Tectonic geodesy refers to the application of modern geodetic measurements (InSAR, GPS) of crustal deformation due to numerous earth processes, like plate movement, earthquakes, volcanoes, isostatic adjustments and so on and modelling of measured deformation from GPS to understand processes responsible for them. Researchers from several national research institutes (e.g. CSIR-NGRI,CSIR4PI, IIG, WIHG, SOI and ISR) and universities have established GPS stations for monitoring the crustal deformation over the Indian shield region and in the plate boundary regions like Himalaya and Andaman. Many campaign mode and about 100 semi-permanent/ permanent GNSS/GPS measurements have been providing the up-to-date comprehension of crustal deformation continuously enriching our knowledge of dynamics of the different tectonic regions of the Indian plate (Gahalaut et al., 2008; Catherine et al., 2015; Mahesh et al., 2012a; Gahalaut et al., 2013; Jade et $a l, 2017)$. Analyses of GPS data from peninsular India indicate that there are no significant internal intraplate deformations; however, there are a few regions like a part of Godavari Rift basin which shows crustal deformation (Mahesh et al., 2012b). Continuous GPS data from Andaman region have allowed constraining the recurrence time of large earthquakes (Gahalaut et al., 2006; Jade et al., 2005; Catherine et al., 2014). Several new findings reported from GPS observations from NE Himalaya and Karakoram have important implications for the seismic hazard of the region (Jade et al., 2007; Mukul et al., 2010; Gahalaut and Kundu,
2012). 25 years of GPS data (campaign mode and continuous) from central and western Himalaya offer a new finding of total arc normal shortening, slip and an estimate of locked fault widthof $\sim 110 \mathrm{~km}$ (Kundu et al., 2014).

\section{Tidal Observations}

The responsibility of carrying out systematic tidal observations and monitoring of tidal stationswas entrusted to SOI in 1877 and since then data is beingcollected continuously at tidal observatories located along East and West Coasts and also Andaman $\&$ Nicobar and Lakshadweep Islands. Sea-Level data from about 24 Tidal observatories, collected during the last 10 decades, is utilized mainly to determine Mean Sea-Level to serve as the Vertical Control Datum for heights for the country, tidal predictions for navigational purposes and for estimation of long time sea level changes. Tide tables are printed a year in advance and made available to National/ International users to facilitate their navigational activities. Tiwari et al., (2004) analysed the Indian ocean sea level changes and ascribed the changes in terms of warming and cooling of the ocean. The mean sea level (1993-1999) estimated from T/P altimetry (Tiwari et al., 2005), which compares well with tide gauge records, seems to be a part of decadal variations of sea level in the Indian ocean.Catherine et al. (2014) analyzed the sea level variations from satellite altimetry data and tide gauge from Andaman Islands for tectonic studies. During the past decade, state-of-the-art digital tide-gauges at $\sim 30$ locations along the Indian coast have been established and connected to the dedicated VSAT network for real-time tidal data transmission to the centrally located hub at National Tidal Data Centre, G\&RB, SOI. This near real-time tidal data is also shared with the National Early Tsunami Warning Centre, INCOIS, Hyderabad for the issuance of a tsunami warning in the event of any eventuality. Extensive analysis of tidal data is carried out for extreme events like Tsunami, storm surge, cyclone, etc.

\section{Planetary Gravity Studies}

Satellite-Satellite tracking technique can provide recovery of gravitational ûeld with high-resolution data of the Moon with the help of Gravity Recovery and Interior Laboratory (GRAIL) mission. Detailed analyses were carried out by Satyakumar et al. (2018) 
and GRGM900C gravity anomaliesare derived from GRAIL mission and topography over the Lunar far side covering the major impact basins to understand subsurface structure. The observed nature of gravity anomalies and crustal thickness are attributed to the buried impact crater under this region. The structure and evolution of the near and far side of the Moon have been studied using integrated analysis of Freeair, Bouguer gravity anomalies of the Moon along with morphological and structural information derived from various remote sensing datasets. Gravity anomalies of Venus are also computed using gravity model (MGNP180U) derived from Magellan mission. Inversion of Bouguer gravity anomalies resulted in computation ofcrustal thickness map of Venus.

\section{New Initiatives}

Considering the global development in the field of Geodesy, its importance in strengthening the National Mapping and Geodetic organizations and requirement

\section{References}

Arora B R, Kumar A, Rawat G, Kumar N and Choubey V M (2008) First observations of free oscillations of the earth from Indian superconducting gravimeter in Himalaya Current Science 95 1611-1617

Arora K, Tiwari V M, Mishra D C and Singh B (2006) Use of 3D interpretation techniques of the geopotential field in mapping the offshore extent of the deccan volcanic province Journal of Geophysics 27 67-74

Arora K, Tiwari V M, Singh B, Mishra D C and Grevemeyer I (2012) Three dimensional lithospheric structure of the western continental margin of India constrained from gravity modelling: implication for tectonic evolution Geophysical Journal International 190 131-150

Asoka A, Gleeson T, Wada Y and Mishra V (2017) Relative contribution of monsoon precipitation and pumping to changes in groundwater storage in India Nature Geoscience 10 109-117

Aung T H, Singh A M and Prasad U W (2009) Sea level threat in Tuvalu American Journal of Applied Sciences 6 1169-1174

Banerjee C and Kumar D N (2014) Identification of prominent spatio-temporal signals in GRACE derived terrestrial water storage for India The International Archives of Photogrammetry, Remote Sensing and Spatial Information Sciences 40 333-338 of human resources in this field, a "National Programme on Geodesy" has been launched by the Department of Science \& Technology, Government of India, with the following objectives:

1. To build up the capacity in different aspects of Geodesy in Indian institutions.

2. To strengthen the Human Resource Development in Geodesy in the country.

3. To address the need of National Mapping and Geodetic organizations.

\section{Acknowledgments}

Authors are thankful to the Director, CSIR-NGRI for permission to publish this paper. We also would like to thank Prof. H K Gupta for inviting us to write this article and several suggestions to improve the manuscript.

Banerjee C and Kumar D N (2016) Inter-comparison of GRACE data over India. In Land Surface and Cryosphere Remote Sensing III 9877 (doi:10.1117/12.2223498)

Bansal A R, Fairhead J D, Green C M and Fletcher K M (2005) Revised gravity for offshore India and the isostatic compensation of submarine features Tectonophysics $\mathbf{4 0 4}$ $1-22$

Barik B, Ghosh S, Sahana A S, Pathak A and Sekhar M (2017) Water-food-energy nexus with changing agricultural scenarios in India during recent decades Hydrology and Earth System Sciences 21 3041-3060

Bastia R, Radhakrishna M, Srinivas T, Nayak S, Nathaniel D M and Biswal T K (2010) Structural and tectonic interpretation of geophysical data along the Eastern Continental Margin of India with special reference to the deep water petroliferous basins $J$ Asian Earth Sciences 39 608-619

Bhanja S N, Mukherjee A, Rodell M, Wada Y, Chattopadhyay S, Velicogna I, Pangaluru K and Famiglietti J S (2017b) Groundwater rejuvenation in parts of India influenced by water-policy change implementation Scientific reports 7 7453(1-7)

Bhanja S N, Mukherjee A, Saha D, Velicogna I and Famiglietti J S (2016) Validation of GRACE based groundwater storage anomaly using in-situ groundwater level measurements in India $J$ Hydrology 543 729-738 
Bhanja S N, Rodell M, Li B, Saha D and Mukherjee A (2017a) Spatio-temporal variability of groundwater storage in India J Hydrology 544 428-437

Bhattacharyya R, Verma P K and Majumdar T J (2009) High resolution satellite geoids/gravity over the western Indian offshore for tectonics and hydrocarbon exploration Indian Journal of Marine Sciences 38 116-125

Bowin C (2000) Mass anomaly structure of the Earth. Reviews of Geophysics 38(3) 355-387

Carrion D, Kumar N, Barzaghi R, Singh A P and Singh B (2009) Gravity and geoid estimate in South India and their comparison with EGM2008 Newton's Bulletin 4 275-283

Catherine J K, Gahalaut V K, Kundu B, Ambikapathy A, Yadav R K, Bansal A, Narsaiah M and Naidu S M (2015) Low deformation rate in the Koyna-Warna region, a reservoir triggered earthquake site in west-central stable India Journal of Asian Earth Sciences 97 1-9

Catherine J K, Gahalaut V K, Srinivas N, Kumar S and Nagarajan B (2014) Evidence of strain accumulation in the Andaman region for the giant 2004 Sumatra Andaman earthquake Bulletin of the Seismological Society of America 104587 591

Chand S, Radhakrishna M and Subrahmanyam C (2001) IndiaEast Antarctica conjugate margins: Rift-shear tectonic setting inferred from gravity and bathymetry data Earth and Planetary Science Letters 185 225-236

Chatterjee S, Bhattacharyya R, Michael L, Krishna K S and Majumdar T J (2007) Validation of ERS-1 and highresolution satellite gravity with in-situ shipborne gravity over the Indian offshore regions: Accuracies and implications to subsurface modeling Marine Geodesy 30 197-216

Chauhan V, Khandelwal D D and Kumar N (2016) A comparative study of gravity and crustal deformation data through superconducting gravimeter and GPS observations in the North-West Himalayan region Episodes 39 599-603

Chinnasamy P, Misra G, Shah T, Maheshwari B and Prathapar S (2015) Evaluating the effectiveness of water infrastructures for increasing groundwater recharge and agricultural production-A case study of Gujarat, India Agricultural Water Management 158 179-188

Dasgupta S, Das I C, Subramanian S K and Dadhwal V K (2014) Space-based gravity data analysis for groundwater storage estimation in the Gangetic plain, India Current Science $107832-844$

Desa M A, Ismaiel M, Suresh Y and Krishna K S (2018) Oblique strike-slip motion off the Southeastern Continental Margin of India: Implication for the separation of Sri Lanka from India Journal of Asian Earth Sciences 156 111-121
Dubey C P, Tiwari V M and Rao P R (2017) Insights into the Lurking Structures and Related Intraplate Earthquakes in the Region of Bay of Bengal Using Gravity and Full Gravity Gradient Tensor Pure and Applied Geophysics 174 43574368

Dutt Vishwakarma B, Jain K, Sneeuw N and Devaraju B (2013) Mumbai 2005, Bihar 2008 flood reflected in mass changes seen by GRACE satellites Journal of the Indian Society of Remote Sensing 41 687-695

Featherstone W E (1997) On the use of the Geoid in Geophysics: A case study over the north-west shelf of Australia Exploration Geophysics 28 52-57

Gahalaut V K and Kundu B (2012) Possible influence of subducting ridges on the Himalayan arc and on the ruptures of great and major Himalayan earthquakes Gondwana Research 21 1080-1088

Gahalaut V K, Jade S, Catherine J K, Gireesh R, Ananda M B, Kumar P, Narsaiah M, Jafri S S, Ambikapathy A, Bansal A, Chadha R K (2008) GPS measurements of postseismic deformation in the Andaman-Nicobar region following the giant 2004 Sumatra-Andaman earthquake Journal of Geophysical Research: Solid Earth 113 B8

Gahalaut V K, Kundu B, Laishram S S, Catherine J, Kumar A, Singh M D, Tiwari R P, Chadha R K, Samanta S K, Ambikapathy A and Mahesh P (2013) Aseismic plate boundary in the Indo-Burmese wedge, northwest Sunda Arc Geology 41 235-238

Gahalaut V K, Nagarajan B, Catherine J K and Kumar S (2006) Constraints on 2004 Sumatra-Andaman earthquake rupture from GPS measurements in Andaman-Nicobar Islands Earth and Planetary Science Letters 242 365-374

Gahalaut V K, Yadav R K, Sreejith K M, Gahalaut K, Bürgmann R, Agrawal R, Sati S P and Bansal A (2017) InSAR and GPS measurements of crustal deformation due to seasonal loading of Tehri reservoir in Garhwal Himalaya, India Geophysical Journal International 209 425-433

Gautam P K, Arora S, Kannaujiya S, Singh A, Goswami A and Champati P K (2017a) A comparative appraisal of ground water resources using GRACE-GPS data in highly urbanised regions of Uttar Pradesh, India Sustainable Water Resources Management 3 441-449

Gautam P K, Gahalaut V K, Prajapati S K, Kumar N, Yadav R K, Rana N and Dabral C P (2017b) Continuous GPS measurements of crustal deformation in Garhwal-Kumaun Himalaya Quaternary International 462 124-129

Ghosh A, Thyagarajulu G and Steinberger B (2017) The importance of upper mantle heterogeneity in generating the Indian Ocean geoid low Geophysical Research Letters 


\section{9707-9715}

Ghosh J K and Mishra U N (2016) Determination of Geoid Undulation by Astro-Geodetic Method Journal of Surveying Engineering 14205015007

Goyal P and Tiwari V M (2014) Application of the continuous wavelet transform of gravity and magnetic data to estimate sub-basalt sediment thickness Geophysical Prospecting 62 148-157

Goyal R, Dikshit O and Nagarajan B (2018) Evaluation of global geopotential models: a case study for India. Survey review https://doi.org/10.1080/00396265.2018.1468537

Gravity Map of Series of India (GMSI) (1978), Gravity anomaly maps of India on 1:5 million scale, 1-4, National Geophysical Research Institute, Hyderabad, India

Gravity Map of Series of India (GMSI) (2006) Gravity anomaly maps of India on 1:2 million scale published by Geological Survey of India; GSI, Hyderabad, India

Grevemeyer I and Tiwari V M (2006) Overriding plate controls spatial distribution of megathrust earthquakes in the SundaAndaman subduction zone Earth and Planetary Science Letters 251 199-208

Gulatee B L (1956) Gravity data in India Survey of India Technical Paper 10 1-95

Gupta H K, Arora K, Rao N P, Roy S, Tiwari V M, Patro P K, Satyanarayana H V S, Shashidhar D, Mahato C R, Srinivas K N S S S and Srihari M (2017) Investigations of continued reservoir triggered seismicity at Koyna, India Geological Society, London, Special Publications 445 151-188

Gupta H, Rao N P, Roy S, Arora K, Tiwari V M, Patro P K, Satyanarayana H V S, Shashidhar D, Mallika K, Akkiraju V V and Goswami D (2015) Investigations related to scientific deep drilling to study reservoir-triggered earthquakes at Koyna, India International Journal of earth sciences 104 1511-1522

Hackney R (2004) Gravity anomalies, crustal structure and isostasy associated with the Proterozoic Capricorn Orogen, Western Australia Precambrian Research 128 219-236

Hari Narain, Qureshy M N and Appa Rao V (1964) Gravity studies geophysics in India Bulletin NGRI 1 63-76

Jade S, Ananda M B, Kumar P D and Banerjee S (2005) Coseismic and post-seismic displacements in Andaman and Nicobar Islands from GPS measurements Current Science 88 1980-1984

Jade S, Mukul M, Bhattacharyya A K, Vijayan M S M, Jaganathan S, Kumar A, Tiwari R P, Kumar A, Kalita S, Sahu S C and Krishna A P (2007) Estimates of interseismic deformation in Northeast India from GPS measurements Earth and
Planetary Science Letters 263 221-234

Jade S, Shrungeshwara T S, Kumar K, Choudhury P, Dumka R K and Bhu H (2017) India plate angular velocity and contemporary deformation rates from continuous GPS measurements from 1996 to 2015 Scientific Reports 7 11439(1-16)

Kailasam L N, Murty B G K and Chayanulu A Y S R (1972) Regional gravity studies of the Deccan Trap areas of Peninsular India Current Science 41 403-407

Kalra R, Rao G S, Fainstein R, Radhakrishna M, Bastia R and Chandrashekar S (2014) Crustal architecture and tectonomagmatic history of the western offshore of India: Implications on deepwater sub-basalt hydrocarbon exploration Journal of Petroleum Science and Engineering 122 149-158

Kar Y C, Satyanarayana G V, Nandi B K and Pathan M S (2015) Depositional environment and structural features inferred from geophysical surveys off Pentakota, Andhra Pradesh coast, Bay of Bengal Indian Journal of Geosciences 69 273-286

Khan H H, Khan A, Ahmed S, Gennero M C, Do Minh K and Cazenave A (2013) Terrestrial water dynamics in the lower Ganges-estimates from ENVISAT and GRACE Arabian Journal of Geosciences 6 3693-3702

Khandelwal D D, Gahalaut V, Kumar N, Kundu B and Yadav R K (2014) Seasonal variation in the deformation rate in NW Himalayan region Natural hazards 74 1853-1861

Kumar N, Zeyen H and Singh A P (2014) 3D lithosphere density structure of southern Indian Shield from joint inversion of gravity, geoid and topography data Journal of Asian Earth Sciences 89 98-107

Kumar N, Zeyen H, Singh A P and Singh B (2013) Lithospheric structure of southern Indian shield and adjoining oceans: integrated modelling of topography, gravity, geoid and heat flow data Geophysical Journal International 194 30-44

Kundu B, Vissa N K and Gahalaut V K (2015) Influence of anthropogenic groundwater unloading in Indo Gangetic plains on the 25 April $2015 \mathrm{Mw} 7.8$ Gorkha, Nepal earthquake Geophysical Research Letters 42 10,607-0,613, doi:10.1002/ 2015GL066616

Kundu B, Vissa N K, Panda D, Jha B, Asaithambi R, Tyagi B and Mukherjee S (2017) Influence of a meteorological cycle in mid-crustal seismicity of the Nepal Himalaya Journal of Asian Earth Sciences 146 317-325

Kundu B, Yadav R K, Bali B S, Chowdhury S and Gahalaut V K (2014) Oblique convergence and slip partitioning in the NW Himalaya: implications from GPS measurements Tectonics 33 2013-2024 
Li X and Götze H-J (2001) Tutorial: ellipsoid, geoid, gravity, geodesy, and geophysics Geophysics 66 1660-1668

Mahesh P, Catherine J K, Gahalaut V K, Kundu B, Ambikapathy A, Bansal A, Premkishore L, Narsaiah M, Ghavri S, Chadha R K and Choudhary P (2012a) Rigid Indian plate: constraints from GPS measurements Gondwana Research 22 1068-1072

Mahesh P, Gahalaut V K, Catherine J K, Ambikapathy A, Kundu B, Bansal A, Chadha R K and Narsaiah M (2012b) Localized crustal deformation in the Godavari failed rift, India Earth and Planetary Science Letters 333-334 46-51

Majumdar T J and Bhattacharyya R (2014) High resolution satellite gravity over a part of the Sir Creek offshore on west northwest margin of the Indian subcontinent Indian Journal of Marine Sciences 43 337-339

Majumdar T J and Chander S (2016) On extraction of linear and anomalous features over a part of the $85^{\circ} \mathrm{E}$ Ridge, Bay of Bengal for tectonic studies Indian Journal of Marine Sciences 45 365-370

Majumdar T J, Bhattacharyya R and Krishna K S (2018) On lithospheric studies utilizing geoid/gravity anomalies over the Enderby Basin, Antarctica Indian Journal of Marine Sciences 47 937-944

Majumdar T J, Mohanty K K, Mishra D C and Arora K (2001) Gravity image generation over the Indian subcontinent using NGRI/EGM96 and ERS-1 altimeter data Current Science 80 542-554

Manghnani M H and Woollard G P (1963) Establishment of north-south gravimetric calibration line in India Journal of Geophysical Research 68 6293-6301

Marsh J G (1979) Satellite derived gravity maps. A geophysical atlas for interpretation of satellite derived data, Section 2 (eds) Lowman P D and Fray H V, NASA, Greenbelt, USA 9-14

Mishra D C (2011) Continental margins offshore west and east coasts of India based on satellite gravity and seismic sections-seaward dipping reflectors Current Science 101 1143-1145

Mishra D C (2011) Gravity and Magnetic Methods for Geological Studies: Principles, Integrated Exploration and Plate Tectonics. CRC Press, Taylor and Francis group

Mishra D C and Rajasekhar R P (2005) Tsunami of 26 December 2004 and related tectonic setting Current Science 88 680682

Mishra D C and Ravikumar M (2012) Long and short wavelengths of Indian Ocean geoid and gravity lows: Mid-to-upper mantle sources, rapid drift and seismicity of Kachchh and
Shillong plateau, India Journal of Asian Earth Sciences 60 212-224

Mishra D C, Arora K and Tiwari V M (2004) Gravity anomalies and associated tectonic features over the Indian Peninsular Shield and adjoining ocean basins Tectonophysics 37961 76

Mishra D C, Ravikumar M and Arora K (2012) Long wavelength satellite gravity and geoid anomalies over Himalaya, and Tibet: Lithospheric structures and seismotectonics of deep focus earthquakes of Hindu Kush-Pamir and Burmese arc Journal of Asian Earth Sciences 48 93-110

Mishra D C, Tiwari V M and Singh B (2008) Geological significance of gravity studies in Memoir of Geological Society of India 66 329-372

Mishra U N and Ghosh J K (2016) Development of a gravimetric geoid model and a comparative study Geodesy and Cartography $\mathbf{4 2}$ 75-84

Mishra U N and Ghosh J K (2017) Development of a Geoid Model by Geometric Method Journal of the Institution of Engineers (India): Series A 98 437-442

Mishra V, Aadhar S, Asoka A, Pai S and Kumar R (2016) On the frequency of the 2015 monsoon season drought in the Indo-Gangetic Plain Geophysical Research Letters 43 10212,112

Mukherjee A and Ramachandran P (2018) Prediction of GWL with the help of GRACE TWS for unevenly spaced time series data in India: Analysis of comparative performances of SVR, ANN and LRM Journal of Hydrology 558 647658

Mukhopadhyay R, Rajesh M, De S, Chakraborty B and Jauhari P (2008) Structural highs on the western continental slope of India: Implications for regional tectonics Geomorphology 96 48-61

Mukul M, Jade S, Bhattacharyya A K and Bhusan K (2010) Crustal shortening in convergent orogens: Insights from global positioning system (GPS) measurements in northeast India Journal of the Geological Society of India 75 302312

Murthy B V S, Varaprasad S M and Bhimasankar V L S (1976) Gravity base stations established by Center of Exploration Geophysics Geophysical Research Bulletin 14 49-55

Nagarajan B and S K Singh (2010) Orthometric heights from GPS-levelling observations. Geospatial World. https:// www.geospatialworld.net/article/orthometric-heightsfrom-gps-levelling-observations/

Nair N, Anand S P, Rajaram M and Rao P R (2015) A relook into the crustal architecture of Laxmi Ridge, northeastern 
Arabian Sea from geopotential data Journal of Earth System Science 124 613-630

Nandi B K and Rao P R 2015 Geophysical analysis of sediment deposited since Late Quaternary period in parts of Ganga prodelta area off Sagar Island, Bay of Bengal, India Indian Journal of Geosciences 69 253-260

Narayan S, Sahoo S D, Pal S K, Kumar U, Pathak V K, Majumdar $\mathrm{T} J$ and Chouhan A(2017) Delineation of structural features over a part of the Bay of Bengal using total and balanced horizontal derivative techniques Geocarto international 32 351-366

Pal S K and Majumdar T J (2015) Geological appraisal over the Singhbhum-Orissa Craton, India using GOCE, EIGEN6$\mathrm{C} 2$ and in situ gravity data International Journal of Applied Earth Observation and Geoinformation 35 96-119

Pal S K, Majumdar T J, Pathak V K, Narayan S, Kumar U and Goswami O P (2016) Utilization of high-resolution EGM2008 gravity data for geological exploration over the Singhbhum-Orissa Craton, India Geocarto International $31783-802$

Pal S K, Narayan S, Majumdar T J and Kumar U (2016) Structural mapping over the $85^{\circ} \mathrm{E}$ Ridge and surroundings using EIGEN6C4 high-resolution global combined gravity field model: an integrated approach Marine Geophysical Research 37 159-184

Panda D K and Wahr J (2016) Spatiotemporal evolution of water storage changes in India from the updated GRACE-derived gravity records Water Resources Research 52 135-149

Panda D K, AghaKouchak A and Ambast S K (2017) Increasing heat waves and warm spells in India, observed from a multiaspect framework Journal of Geophysical Research: Atmospheres 122 3837-3858

Prajapat S K and B Singh (2010) Isostatic geoid anomalies over the plateau region of Central India, SPG Conference Extended abstract SPG-2010 Hyderabad

Prasad K N D, Srinivas N, Meshram A E, Singh A P and Tiwari V M (2017) Co-seismic gravity changes in the Koyna-Warna region: Implications of mass redistribution Journal of the Geological Society of India 90 704-710

Qureshy M N and Krishna Brahmam N (1969) Gravity bases established in India by NGRI-Part I Bulletin NGRI 731 49

Qureshy M N and Warsi W E K (1972) Gravity bases established in India by NGRI, Part II Geophysical Research Bulletin $10141-152$

Qureshy M N and Warsi W E K (1973) Gravity bases established in India by NGRI, Part III Geophysical Research Bulletin
$119-16$

Qureshy M N, Subba Rao D V, Bhatia S C, Aravamadhu P S and Subrahmanyam C (1973) Gravity bases established in India by NGRI Part IV Geophysical Research Bulletin 11 136152

Radhakrishna M, Chand S and Subrahmanyam C (2000) Gravity anomalies, sediment loading and lithospheric flexure associated with the Krishna-Godavari basin, eastern continental margin of India Earth and Planetary Science Letters 175 223-232

Radhakrishna M, Kurian P J, Nambiar C G and Mohan S K (1998) Gravity bases established by Cochin University of Science and Technology (CUSAT) over parts of northern Kerala Journal of the Geological Society of India 51 393398

Radhakrishna M, Lasitha S and Mukhopadhyay M (2008) Seismicity, gravity anomalies and lithospheric structure of the Andaman arc, NE Indian Ocean Tectonophysics 460 248-262

Radhakrishna M, Subrahmanyam C and Twinkle D (2010) Thin oceanic crust below Bay of Bengal inferred from 3-D gravity interpretation Tectonophysics 493 93-105

Radhakrishna M, Twinkle D, Nayak S, Bastia R, Srinivasa Rao G (2012) Crustal structure and rift architecture across the Krishna-Godavari basin in the central Eastern Continental Margin of India based on analysis of gravity and seismic data Marine and Petroleum Geology 37 129-146

RadhaKrishna M, Verma R K and Purushotham A K (2002) Lithospheric structure below the eastern Arabian Sea and adjoining west coast of India based on integrated analysis of gravity and seismic data Marine Geophysical Researches $2325-42$

Rajesh R S and Mishra D C (2003) Admittance analysis and modelling of satellite gravity over Himalayas-Tibet and its seismogenic correlation Current Science 84 224-230

Rajesh S and Majumdar T J (2003) Geoid generation and subsurface structure delineation under the Bay of Bengal, India using satellite altimeter data Current Science 84 14281436

Rajesh S and Majumdar T J (2014) Effects of Ninetyeast Ridge magmatism and pre India-Eurasia collision dynamics on basement and crust-lithospheric structures of the northeastern Indian Ocean Journal of the Geological Society of India $\mathbf{8 4}$ 531-543

Rajesh S, Majumdar T J and Krishna K S (2015) Lithospheric stretching and the long wavelength free-air gravity anomaly of the Eastern Continental Margin of India and the $85 \mathrm{O} \mathrm{E}$ ridge, Bay of Bengal Indian Journal of Marine Sciences 44 
783-794

Raju S M (2018) Prof C Mahadevan endowment lecture on National Mineral Exploration Policy-2016: Initiatives of geological survey of India Journal of the Geological Society of India 91 127-129

Rao D G, Paropkari A L, Krishna K S, Chaubey A K, Ajay K K and Kodagali V N (2010) Bathymetric highs in the midslope region of the western continental margin of IndiaStructure and mode of origin Marine Geology 276 58-70

Rao G S and Radhakrishna M (2014) Crustal structure and nature of emplacement of the $85 \mathrm{E}$ Ridge in the Mahanadi offshore based on constrained potential field modeling: Implications for intraplate plume emplaced volcanism Journal of Asian Earth Sciences 85 80-96

Rao G S and Radhakrishna M (2016) A Comparative Account of Terrestrial and Satellite Based Potential Field Data for Regional Tectonic/Structural Interpretation and Crustal Scale Modeling With Reference to the Indian Region International Journal of Earth Sciences and Engineering 10 903-914

Rao G S, Kumar M and Radhakrishna M (2018) Structure, mechanical properties and evolution of the lithosphere below the northwest continental margin of India International Journal of Earth Sciences https://doi.org/ 10.1007/s00531-018-1594-x

Rao G S, Radhakrishna M and Murthy K S R (2015) A seismotectonic study of the 21 May 2014 Bay of Bengal intraplate earthquake: evidence of onshore-offshore tectonic linkage and fracture zone reactivation in the northern Bay of Bengal Natural Hazards 78 895-913

Rao G S, Radhakrishna M, Sreejith K M, Krishna K S and Bull J M (2016) Lithosphere structure and upper mantle characteristics below the Bay of Bengal Geophysical Journal International 206 675-695

Ravikumar M, Mishra D C and Singh B (2013a) Lithosphere, crust and basement ridges across Ganga and Indus basins and seismicity along the Himalayan front, India and Western Fold Belt, Pakistan Journal of Asian Earth Sciences $\mathbf{7 5}$ 126-140

Ravikumar M, Mishra D C, Singh B, Raju D C V and Singh M (2013b) Geodynamics of NW India: subduction, lithospheric flexure, ridges and seismicity Journal of the Geological Society of India 81 61-78

Satishkumar B, Muralikrishnan S, Narendran J, Venkataraman V R and Dadhwal V K (2013) Bias-corrected GOCE geoid for the generation of high-resolution digital terrain model Current Science 104 940-943

Satyakumar A V, Rajasekhar R P and Tiwari V M (2018) Gravity anomalies and crustal structure of the Lunar far side highlands Planetary and Space Science

Singh AK, Jasrotia A S, Taloor A K, Kotlia B S, Kumar V, Roy S, Ray P K C, Singh K K, Singh A K and Sharma A K (2017) Estimation of quantitative measures of total water storage variation from GRACE and GLDAS-NOAH satellites using geospatial technology Quaternary International 444 $191-200$

Singh A P, Kumar N and Zeyen H (2015) Three-dimensional lithospheric mapping of the eastern Indian shield: A multiparametric inversion approach Tectonophysics 665 164176

Singh B and Diljith D T (2009) January Structural fabric of Krishna-Godavari basin on the eastern continental margin of India inferred from the analysis of land and satellite gravity data. In 2009 SEG Annual Meeting Society of Exploration Geophysicists

Singh B, Raju D C V, Rao B N and Purushotham S (2012) Analysis of gravity and magnetic fields over a part of KrishnaGodavari basin, India-inference on structures and nature of the basement. In Istanbul 2012-International Geophysical Conference and Oil \& Gas Exhibition (1-4) Society of Exploration Geophysicists and the Chamber of Geophysical Engineers of Turkey

Singh H N, Panchanathan P V and Unnikrishnan K R (1985) Gravity bases established by the centre for earth sciences studies in and around Palghat region, South India Journal of the Geological Society of India 26 704-711

Singh S K (2007) Development of a high-resolution Gravimetric geoid for Central India. Ph D thesis Dept of Civil Engineering Indian Institute of Technolgy Roorkee Roorkee

Singh S K (2010) Coordinate Transformation between Everest and WGS - 84 Datums. Geospatial World, November

Singh S K and Srivastava R K (2018) Development of geoid model - a case study on western India FIG Congress 2018, Istanbul, turkey, May 6-11, 2018

Singh S K, Nagarajan B and Garg P K (2006) Optimizing gravimetric geoid solution, coordinates

Singh S K, Nagarajan B, Garg P K (2007) Determination of local gravimetric geoid. Coordinates 3 14-19

Sinha D, Syed T H, Famiglietti J S, Reager J T and Thomas R C (2017) Characterizing drought in India using GRACE observations of terrestrial water storage deficit Journal of Hydrometeorology 18 381-396

Soni A and Syed T H (2015) Diagnosing land water storage variations in major Indian river basins using GRACE observations Global and Planetary Change 133 263-271 
Sreejith K M, Rajesh S, Majumdar T J, Srinivasa Rao G, Radhakrishna M, Krishna K S, Rajawat A S (2013) Highresolution residual geoid and gravity anomaly data of the northern Indian Ocean-An input to geological understanding Journal of Asian Earth Sciences 62 616-626

Srinivas N, Tiwari V M, Tarial J S, Prajapti S, Meshram A E, Singh B and Nagarajan B (2012) Gravimetric geoid of a part of south India and its comparison with global geopotential models and GPS-levelling data Journal of earth system science 121 1025-1032

Subba Rao D V, Sarma J R K and Krishna Brahmam N (1982 ) Gravity bases established in India by NGRI-Part V Geophysical Research Bulletin 20 29-35

Subrahmanyam C and Chand S (2006) Evolution of the passive continental margins of India-a geophysical appraisal Gondwana Research 10 167-178

Subrahmanyam C, Gireesh R, Chand S, Raju K K and Rao D G (2008) Geophysical characteristics of the Ninetyeast RidgeAndaman island arc/trench convergent zone Earth and Planetary Science Letters 266 29-45

Tiwari V M (2010) On some recent applications of Gravimetry to Earth Sciences Earth Science India 3 43-53

Tiwari V M and Goyal P (2010) Resolving the Causative Sources of Gravity Anomaly using Spectral Analysis. Summer research Project, IIT, Roorkee

Tiwari V M and Mishra D C (2008) Isostatic compensation of continental and oceanic topographies of Indian lithosphere. Memoir Geol Soc India 68 173-190

Tiwari V M, Cabanes C, DoMinh K and Cazenave A (2004) Correlation of interannual sea level variations in the Indian Ocean from Topex/Poseidon altimetry, temperature data and tide gauges with ENSO Global and Planetary Change 43 183-196

Tiwari V M, Cabanes C, DoMinh K and Cazenave A (2005) Sea level in the Indian ocean from Topex/Poseidon altimetry and tide gauges. 'Oceanology' HK Gupta editor, University Press, Hyderabad 150-168

Tiwari V M, Diament M and Singh S C (2003) Analysis of satellite gravity and bathymetry data over Ninety-East Ridge: Variation in the compensation mechanism and implication for emplacement process. Journal of Geophysical Research: Solid Earth 108 (B2)

Tiwari V M, Grevemeyer I, Singh B and Morgan J P (2007) Variation of effective elastic thickness and melt production along the Deccan-Reunion hotspot track Earth and Planetary Science Letters 264 9-21

Tiwari V M, Mishra D C and Pandey A K (2014b) The lithospheric density structure below the western Himalayan syntaxis: Tectonic implications. Geological Society, London, Special Publications 412 SP412-7

Tiwari V M, Rajasekhar R P and Mishra D C (2009a) Gravity anomaly, lithospheric structure and seismicity of Western Himalayan Syntaxis Journal of seismology 13 363-370

Tiwari V M, Rao M V, Mishra D C and Singh B (2006a) Crustal structure across Sikkim, NE Himalaya from new gravity and magnetic data Earth and Planetary Science Letters $\mathbf{2 4 7}$ 61-69

Tiwari V M, RavikumarM and Mishra D C (2013) Long wavelength gravity anomalies over India: crustal and lithospheric structures and its flexure Journal of Asian Earth Sciences 70 169-178

Tiwari V M, Singh B, Arora K and Kumar S (2010) The potential of satellite gravity and gravity gradiometry in deciphering structural setting of the Himalayan collision zone Current Science 99 1795-1800

Tiwari V M, Singh B, Rao M V and Mishra D C (2006b) Absolute gravity measurements in India and Antarctica Current Science 91 686-689

Tiwari V M, Srinivas N and Singh B (2014a) Hydrological changes and vertical crustal deformation in south India: Inference from GRACE, GPS and absolute gravity data Physics of the Earth and Planetary Interiors 231 74-80

Tiwari V M, Wahr J and Swenson S (2009b) Dwindling groundwater resources in northern India, from satellite gravity observations Geophysical Research Letters 36

Tiwari V M, Wahr J, Swenson S and Singh B (2011) Land water storage variation over Southern India from space gravimetry Current Science 101 536-540

Tripathi R K and Tripathi M (2015) Development of geoid model for Chhattisgarh state using geophysical methods and gps technology. In 4th International conference on Advances in Engineering Sciences and Applied Mathematics, Dec 89, 2015, Kuala Lumpur, Malaysia

Vaish J and Pal S K (2015) Geological mapping of Jharia Coalfield, India using GRACE EGM2008 gravity data: A vertical derivative approach Geocarto International 30 388-401

Vanicek M P and Christou N T (1993) Geoid and its geophysical interpretations. CRC Press

Verma A, Kumar A, Jeganathan C and Kumar S (2016) Analysis of groundwater anomalies using GRACE over various districts of Jharkhand. In Land Surface and Cryosphere Remote Sensing III 9877

Verma R K and Mukhopadhyay M (1984) Gravity field over Singhbhum, its relationship to geology and tectonic history 
Tectonophysics 106 87-107

Verma R K, Mukhopadhyay M, Ashraf M H, Nag A K and Sarma A U S (1979) Gravity bases established in Eastern India by ISM Geophysical Research Bulletin 17 45-56

Walker J T, Haig C T, Basevi J P, Heaviside W J, Campbell W M and Burrard S G (1901) Account of the Operations of the
Great Trigonometrical Survey of India. 16 Printed at the office of the Trigonometrical branch, Survey of India

Yadav R and Tiwari V M (2018) Lithospheric Density Structure of Andaman Subduction Zone from Joint Modelling of Gravity and Geoid data Indian Journal of Geo Marine Sciences 47 931-936. 